\author{
Mahama Tawat
}

The Tip of the Iceberg. Prop. 1975: 26 and its Freedom of Choice Goal in Sweden's Multiculturalism Policy

MIM Working Paper Series 19: 4

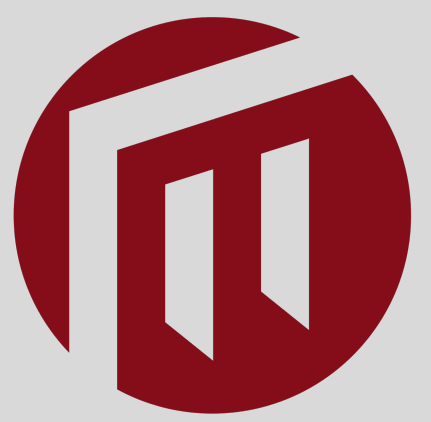




\section{MIM Working Paper Series No 19: 4}

\section{Published}

2019

\section{Editor}

Anders Hellström, anders.hellstrom@mau.se

\section{Published by}

Malmö Institute for Studies of Migration, Diversity and Welfare (MIM) Malmö University

20506 Malmö

Sweden

ISBN 978-91-7877-058-8

doi $10.24834 / 9789178770588$

Online publication

www.bit.mah.se/muep 


\title{
The Tip of the Iceberg. Prop. 1975: 26 and its Freedom of Choice Goal in Sweden's Multiculturalism Policy
}

\author{
ABSTRACT \\ In the expansive literature on Swedish multiculturalism policy, the Freedom of \\ Choice Goal (FCG) of the Bill, Prop. 1975:26, Guidelines for an Immigrant and \\ Minority Policy is often presented as its founding document. But this belies the fact \\ that the Goal was beset by a controversy about its multicultural scope in the years \\ that followed its adoption in 1975 that was never really settled. This article revisits \\ the question and shows that the Goal indeed represented a multicultural vision. \\ However, it was just the tip of an iceberg formed by socioeconomic integration \\ policies. Earlier and more consistent multicultural policy provisions were present \\ most notably in the state cultural policy. The article draws evidence from multiple \\ sources including comparison with Norway.
}

\section{KEYWORDS}

Multiculturalism, Sweden, policy change, divergence, convergence, migration

\section{BIOGRAPHICAL NOTES}

Mahama Tawat is Assistant Professor at National Research University, Higher School of Economics, Moscow and Research Associate at MIM, Malmö University

\section{CONTACT}

Mahama.tawat542@gmail.com 


\section{Introduction}

The debate on multiculturalism policy in Sweden was opened with a bang on 21 October 1964. In an article in the daily newspaper Dagens Nyheter named "The Alien Problem in Sweden," Utlänningsproblemet i Sverige ${ }^{1}$, David Schwarz, a public intellectual and Holocaust survivor of Polish background admonished the government for neglecting immigrants' integration issues. He claimed that while, they had achieved economic status on par with native Swedes, they suffered from many social ills due to discrimination, difficulties with Swedish language acquisition, the absence of social services adapted to their needs, and even differences with the native population in degree of religiosity, temperament and patriotism. He argued that the government's inaction would lead to their "spiritual death", their radicalization into hardcore communists and fascists, and the emigration of the foreign-born working age population that will undermine its economic vitality ${ }^{2}$. Furthermore, he claimed that Sweden's actions in favour of liberation movements in the Third-World would only be credible in the eyes of its own immigrant groups if it showed similar concern for their problems. ${ }^{3} \mathrm{He}$ recommended measures such as equal recognition and material support for immigrant schools and cultural activities as well as subsidies to immigrants' newspapers and churches".

A fierce intellectual debate followed between "the advocates of a mixed culture society "blandkultursamhälle" and the advocates of a multicultural society "flerkultursamhälle." The former stood against state support for immigrants' cultural activities but against forced or mandated assimilation. ${ }^{6}$ The latter believed that in practice such policy would coerce immigrants to assimilate. The state should grant material support to their cultural practices if it wanted to give them a real choice. Groups and not individuals were bearers of cultural rights. ${ }^{7}$ In 1968, after many small-scale initiatives at local and national levels, the government launched a large-scale enquiry into immigrants' integration issues, the Integration Enquiry, Invandrar utredning. In 1975, after seven years of work by the Enquiry, the Government published Bill, Prop. 1975: 26 Guidelines for an Immigrant and Minority Policy that has retained attention as the country's multiculturalism policy through its Freedom of Choice Goal.

\footnotetext{
${ }^{1}$ Schwarz, Utlänningsproblemet i Sverige.

${ }^{2}$ Ibid.

${ }^{3}$ Ibid.

${ }^{4}$ Ibid.

${ }^{5}$ Dalhström Rhetoric, Practice and the Dynamics of Institutional Change, 296 citing Hansen Jämlikhet och valfrihet and Román En invandrarpolitisk oppositionell. For an index of these articles, see Román En invandrarpolitisk oppositionell. For a cross-section of these articles with translation in English see Tawat The Birth of Sweden's Multicultural Policy, 6.

${ }^{6}$ Ibid.

${ }^{7}$ Ibid
} 
However, debate and controversy erupted in the following years on the multicultural scope of the Goal. It was said that it lacked accuracy and was problematic. Its meaning, limitations and attributes were not discussed during preparatory work in the 1970s. It had led to excessive demands by some immigrant groups and acceptance of values that contradict several legislations and government policies. ${ }^{8}$

In the mid-1980s, the government tasked separately the Commission on Immigration, Invandrarpolitiska kommittén (IPOK) in charge of formulating the second Integration Policy, and the Enquiry of Discrimination, Diskrimineringstredningen to also re-examine the three goals namely the Freedom of Choice Goal in their investigations. In its report, SOU 1984:58 Integration and Minority Policy, Invandrar- och minoritetspolitiken, IPOK stated that the Goal had been misinterpreted in many ways. The radical interpretation based on the notion that immigrants were entitled to the preservation of their cultural practices without any checks lacked evidence. ${ }^{9}$ In its opinion, the Freedom of Choice Goal was neutral. ${ }^{10}$ It was neither multiculturalist nor assimilationist. It was observed that where a relativist interpretation was made, it will generate conflict situations in schools. For example, where some immigrants' cultural beliefs (Islamic) about gender equality are at odds with those of the mainstream society. It wondered whether it was not preferable to replace the Goal. The Enquiry on Discrimination came to a similar conclusion but suggested the term "Respect" in replacement, arguing that the state had already resolved to give freedom of choice to Immigrants in the 1970s. ${ }^{11}$ In the end, IPOK formulated a new definition of the concept simply as immigrants' own language and culture. ${ }^{12}$ However, the government rejected the Commission's interpretation and defined freedom of choice as the preservation of the individual's identity and personal integrity as well as the means of enjoying and developing one's cultural activities within the norms of Swedish society. ${ }^{13}$ But yet in another reversal, the government concluded in 1991, in another Bill, Prop. 1990/91:195, that immigrants and not even native Swedes could attain full freedom of choice. ${ }^{14}$ As status quo prevailed and dust settled on the question, it became accepted wisdom that Prop. 1975:26 and its Freedom of Choice Goal is the country's "first" or founding multiculturalism policy. Dahlström who studied both the discourse and the praxis of Sweden's official integration policies between 1964 and 2000 states that policymakers, in essence, adjusted the meaning of the goal to the demand of public opinion. In the 1970s, it subscribed to multiculturalism. In the $1980 \mathrm{~s}$ and 1990s, as public opinion became critical of

\footnotetext{
${ }^{8}$ Prop. 1985/86: 98, About Immigrant Integration Policy 19-20.

${ }^{9}$ Dalhström 2004, 102.

${ }^{10}$ SOU 1984:58, 44.

${ }^{11}$ SOU 1984:58, 48.

12 Prop. 1997/98: 16: 18.

${ }^{13}$ Prop. 1985/86:98.

${ }^{14}$ Prop. 1990/91:195. Soininen, The "Swedish Model" as an Institutional Framework, 689.
} 
multiculturalism, it included elements of interculturalism, albeit with little change in policy implementation. ${ }^{15}$

Quite paradoxically, intrinsic studies of Prop. 1975:26 and follow-up integration policies have emphasized socioeconomic issues, mentioning scantily cultural provisions. According to Jørgensen (2006) and Tawat (2013), Denmark and Swedish official integration policies have focused on employment issues followed by housing issues and language acquisition in the 1970s and anti-discrimination from the 1980s onwards. ${ }^{16}$ Valenta and Bunar ${ }^{17}$ reached similar conclusions in their comparative study of Sweden and Norway. Breidahl ${ }^{18}$ has claimed a greater convergence than assumed between Sweden, Denmark and Norway based on their job activation policies between 1970 and 2011.

\section{Arguments}

The aim of this study is to shed more light on the content of Prop. 1975:26 in view of the controversy that spun off after its adoption in 1975 . The central questions are (1) did policy drafters seek to apply multiculturalism when they formulated the Freedom of Choice Goal? (2) how then do we understand the emphasis laid by various scholars on socioeconomic issues rather than cultural issues in their study of the Bill? It is argued that the Freedom of Choice Goal represented a multicultural vision because it genuinely affirmed immigrants' cultures and granted to the latter material support. However, taken together, the Bill, Prop. 1975:26 emphasized socioeconomic integration and gave only limited space to cultural issues. Thus, the metaphor of the Freedom of Choice Goal as the "tip" of the iceberg.

\section{Immigrant Integration and Policymaking Theory}

Broadly defined, policy is what a government wants to do or not to do. ${ }^{19}$ More specifically, Page distinguishes two kinds of policy: "intentions and actions". Intentions consist of policy principles and policy lines. The former are "general views about how a policy should be conducted." For example, a policy whose goal is to increase the labour participation of immigrants but which does not mention any specific means. Policy lines incorporate more specific goals such as, the delivery of Swedish language courses to immigrants to improve their qualifications for the labour market.

Policy actions fall into the two categories of measures and practices. Policy measures are "specific instruments that give effect to distinct policy lines" and practices are the

\footnotetext{
${ }^{15}$ Dahlström, Rhetoric, Practice and the Dynamics of Institutional Change.

${ }^{16}$ Jørgensen, Dansk realisme og svensk naivitet?

${ }^{17}$ Valenta and Bunar, State-Assisted Integration

${ }^{18}$ Breidahl, Når staten lære

${ }^{19}$ Hague et al. Comparative Government and Politics, 255-256
} 
patterns of behaviour expressed by those in charge of implementing those measures. ${ }^{20}$ The policy process is commonly divided into five stages (the stages heuristic): (1) agendasetting, (2) policy formulation, (3) decision-making, (4) policy implementation and (5) policy evaluation. The study focuses on policy formulation, specifically problem definition or what policymakers do once the problem is on their table ${ }^{21}$ and the identification of contents. It eschews agenda-setting, the process by which an issue climb on policymakers' tables among a myriad of competing ones, decision making, policy implementation and policy evaluation.

Immigrant integration, in contrast to immigration control (access to a country), relates to the processes that immigrants undergo once they reside in a country. The literature on immigrant integration policy is transversed by several approaches, the most prevalent of which is the multiculturalism/assimilation dichotomy. ${ }^{22}$ Generally speaking, multiculturalism designates policies that give equal recognition to immigrants' cultures. Assimilation refers to those that encourage immigrants to abandon or at least keep their cultural beliefs and practices in the private sphere. However, both perspectives have been said to observe a liberal minimum by excluding immigrants' cultural practices or beliefs that they find unacceptable or harmful to the majority such as honour crimes, forced marriages and female genital mutilation ${ }^{23}$

But the multiculturalism/assimilation approach has been besieged by criticisms for its 'catch-all' nature ${ }^{24}$ or having become stretched. That is, the object of 'vague, amorphous conceptualizations' outside its original settings. ${ }^{25}$ For example, multiculturalism has been said to conflate policies towards immigrants across time and policy domains, immigrants' own strategies of acculturation, ${ }^{26}$ ethnic diversity in daily life ${ }^{27}$ and even preparationism "which fosters cultural differences with the intent of preparing for the expulsion or departure of cultural minorities" 28 This "encompassing reflex", Bertossi and Duyvendak write "cannot be sustained without comparative empirical research on immigrant integration and citizenship in Western European countries incurring considerable problems." 29

\footnotetext{
${ }^{20}$ Page, The Origins of Policy, 210-11.

${ }^{21}$ Dery, Agenda Setting and Problem Definition.

${ }^{22}$ Hartmann and Gerteis, Mapping Multiculturalism.

23 Tawat, Danish and Swedish Immigrants' Cultural Policies.

${ }^{24}$ Hartmann and Gerteis, Mapping Multiculturalism, 19.

${ }^{25}$ Collier and Mahon, Concept Stretching Revisited 845-855, see also Sartori Social Science Concepts).

${ }^{26}$ Berry, Acculturation and Adaptation.

${ }^{27}$ Runblom, Swedish Multiculturalism, 624.

${ }^{28}$ Bleich, From International Ideas, 82

${ }^{29}$ Bertossi and Duyvendak, National Models of Immigrants, 238. See also Wilkes and Pottie-Sherman, Does size really matter 224-225.
} 
Multiculturalism has also been said of being the locus of concept stitching that, according to Weiss, ${ }^{30}$ occurs when:

a common language of problem definition [is] stitched together to permit coalitions to move forward one policy or another for a time... Later, consensus unravels as circumstances change, competing definitions gain adherents, and new coalitions form... analysts, advocates, and policy makers [may also] continue to argue over problem definition as problems are introduced, evidence considered, solutions debated, decisions made, programs implemented, and policies evaluated.

Both concept stitching and concept stretching are common causes of goal ambiguity, a prevalent source of policy failure ${ }^{31}$ for which goal clarity and goal ranking are often prescribed as antidotes. ${ }^{32}$ If indeed, the Freedom of Choice Goal was ambiguous and suffered from concept stretching and/or concept stitching, the circumstances in which it arose would emulate the scenario described above.

However, in the words of Hartmann and Gerteis, there have also been attempts among scholars, to "recognize the important distinctions among recent theories, but... also place seemingly disparate claims into meaningful dialogue with each other." ${ }^{33}$ Interculturalism which can be defined as a fluid exchange between majority and minority cultures has been the most noticeable of these endeavours. Meer and Modood cast it as "encouraging communication, recognising dynamic identities, promoting unity and critiquing illiberal cultural practices" 34 . But according to Wieviorka, " interculturalism functions at a much less sophisticated level, and a much less political one for us to be able to assert that it can act as a substitute" ${ }^{35}$. "At the most" he adds, "it may be possible to envisage it as complementary." ${ }^{36}$ There is equally the literature on "everyday multiculturalism" that emerged as a concept "in the 2000s to mark out the 'fact of diversity'. Wise writes that:

As opposed to policy-oriented multiculturalism focused on group based rights, service provision and legislation, the everyday multiculturalism perspective explores how cultural diversity is experienced and negotiated on the ground in everyday situations such as neighbourhoods, schools, and workplaces, and how social relations and social actors' identities are shaped and reshaped in the process. ${ }^{37}$

Entzinger ${ }^{38}$ has also suggested that one differentiates among integration policy domains and considers each domain as an independent variable although one may still find what

\footnotetext{
${ }^{30}$ Weiss, The Powers of Problem Definition, 98

${ }^{31}$ Sabatier, Effective Policy Implementation. 10.

${ }^{32}$ Rainey, A Theory of Goal Ambiguity. Jung, Developing and Validating New Concepts and Measures of Program Goal Ambiguity.

${ }^{33}$ Hartmann and Gerteis, Mapping Multiculturalism, 222.

${ }^{34}$ Meer and Modood, How does Interculturalism Contrast with Multiculturalism, 175.

35 Wieviorka, Multiculturalism: A Concept to be Redefined.

${ }^{36}$ Ibid.

${ }^{37}$ Wise, Everyday Multiculturalism.

${ }^{38}$ Entzinger, The Dynamics of Integration Policies, 101-106.
} 
Favell ${ }^{39}$ called "traces" of other domains therein. ${ }^{40}$ The socioeconomic domain relates to social rights and employment. The political domain refers to political participation namely the right to vote and citizenship acquisition but also incorporation regimes or the institutional design put in place to help immigrants integrate. ${ }^{41}$ The cultural domain is concerned with state policies towards immigrants' cultural practices and beliefs namely multiculturalism and assimilation.

Lastly, a more empirical and increasingly used approach is the Queen's University Index of Multiculturalism Policies in Contemporary Democracies. ${ }^{42}$ It is based on the following seven variables:

1. constitutional, legislative or parliamentary affirmation of multiculturalism

2. the inclusion of ethnic representation/sensitivity in the mandate of public media or media licensing;

3. exemptions from dress-codes, Sunday-closing legislation etc;

4. allowing dual citizenship;

5. the funding of ethnic group organizations to support cultural activities;

6. the funding of bilingual education or mother-tongue instruction;

7. affirmative action for disadvantaged immigrant groups.

However, only two variables, affirmation of immigrants' cultures and state funding of ethnic group organizations to support their cultural activities have been continuously present and thus can be held constant for a proper systematization of the study. ${ }^{43} \mathrm{We}$ analyze the policies through the lenses of the aforementioned theoretical perspectives.

\section{Methodological Frameworks}

The methodological perspective of the study is qualitative content analysis. It helps to establish meaning from text data through coding and identification of thematic patterns. Hsieh and Shannon ${ }^{44}$ distinguish three main approaches: conventional, directed and summative. "In conventional content analysis", they write, "coding categories are derived directly from the text data. A summative content analysis involves counting and

\footnotetext{
${ }^{39}$ Favell 2001.

${ }^{40}$ For a similar typology see Ager and Strand Indicators of Integration. Portes and Zhou, The New Second Generation.

${ }^{41}$ Soysal, Limits of Citizenship.

${ }^{42}$ Queen's University Index of Multiculturalism Policies

${ }^{43}$ The remaining indicators are associated with developments in the 1990s and sometimes after 2006 such as exemptions from dress codes, accommodations on religious grounds, acceptance of dual citizenship, and affirmative action for disadvantaged immigrant groups. Funding of bilingual education and mother-tongue instruction are present in Denmark's assimilationist policies and therefore redundant. ${ }^{44}$ Hsieh and Shannon, Three Approaches to Qualitative Content Analysis.
} 
comparisons, usually of keywords or content, followed by the interpretation of the underlying context." With a directed approach, the analysis starts with a theory or relevant research findings as guidance for initial codes. ${ }^{45}$ The directed approach is more relevant because the study is theory-laden and foregoes counting to a significant extent. It bridges descriptive and inductive approaches. Categories are derived from Entzinger and Favell's conceptualizations: "socio-economic integration", "cultural integration", “political integration”.

Data were gathered through archival research of the country's' official immigrant integration policies, state cultural policies and even immigration control policies. Analysis of secondary literature (newspapers, academic articles and books) was conducted as well as interviews with some policymakers and experts. The article is divided into three main sections. The first section shows that the policy contents felt overwhelmingly in the category of socioeconomic integration and thus constitute the iceberg. The second section demonstrates that FGC amounted to multiculturalism but was just the tip of the iceberg. The third section makes a cross-comparison with Norwegian policies.

\section{Socioeconomic integration policies: The Iceberg}

\section{A) Workplace and Housing Problems}

In the aftermath of the Second World War, as the Swedish economy enjoyed a period of unprecedented economic growth fuelled by reconstruction in post-war Europe, guest workers were recruited in masse from former Yugoslavia, Turkey and South Europe to fill persistent shortages in the industries. At first, the government was reluctant to take action regarding integration problems. But as the Swedish Trade Union Confederation (LO) and the Swedish Adult Education Association, Studieförbund helped to launch languages courses and Immigrant Bureaus, Invandrarbyråerna, ${ }^{46}$ and the media controversy on immigrants' conditions and multiculturalism began the year before by Schwarz, raged ${ }^{47}$, the Government set up the Taskforce on Integration Issues, Arbetsgruppen för Invandrarfragor. But the work of the Taskforce was criticized by Schwarz and his peers for being a botched work for assimilation and prioritizing employers' needs at immigrants' expenses. ${ }^{48}$ The second piece of legislation, SOU 1966, 55 published in August 1966 but initiated in 1964 dealt mostly with the primary education of Swedish children abroad and those of Swedish expatriates at boarding schools in Sweden. According to Schwarz ${ }^{49}$, its neglect for the schooling needs of ethnic

\footnotetext{
${ }^{45}$ Ibid., 1277.

${ }^{46}$ Sarstrand, De första invandrarbyråerna, 50-64. Borevi, Invandrarbyrån i Uppsala.

${ }^{47}$ Tawat, The Birth of Sweden's Multicultural Policy.

${ }^{48}$ Hansen, Jämlikhet och valfrihet, 135-136.

${ }^{49}$ Schwarz, D. 1971. Svensk Invandrar- och Minoritetspolitik 1945-1968, 17.
} 
and religious minorities was due to the absence of minority members in the Commission and the negative attitude of most members towards multiculturalism. Indeed, the Government had itself in its terms of reference prohibited these members from dealing with multiculturalism ${ }^{50}$.

The third legislation concerning immigrants, Prop. 1968: 142 Guidelines for an Alien Policy released in 1968 and its preliminary report, SOU 1967: 18 were geared towards immigration regulation rather than integration issues. Nonetheless, it underlined the importance of Swedish language acquisition for the integration of labor immigrants and the acuteness of housing problems. ${ }^{51}$ It described clearly the tenets of the debate on assimilation and multiculturalism also termed "integration", but refrained from taking any position in favour or against. Furthermore, Rune B. Gunnarsson, the Minister of the Interior guarded against material support to immigrant groups that it claimed would be an infringement of the uniformizing principle of the welfare state. ${ }^{52}$

In May 1968, the government created a fully-fledged commission to investigate the general situation of immigrants and national minorities, Immigrant Enquiry, Invandrarutredning, (IU). In 1971, IU produced a first report SOU 1971: 51 that proposed the introduction of home language instruction for immigrant children alongside Swedish language seen as leading to improved proficiency in Swedish, important for the development of children's personality and the preservation of their cultural heritage. ${ }^{53}$ A second report, SOU 1972: 83, published in 1972, dealt with translation services and the Nordic Convention on Languages. A third report, SOU 1974: 69 issued in 1974 included main findings and formed the basis of Prop.1975: 26 Guidelines for an Integration and Minority Policy adopted by the Riksdag, the Swedish parliament on 22 February 1975.

The Bill formulated three overarching principles: Equality, Freedom of Choice and Cooperation. Equality meant that immigrants should have the same opportunities, rights and obligations. ${ }^{54}$ Freedom of Choice entailed that immigrants have the possibility of choosing to what extent they want to either adopt Swedish culture or preserve and develop their cultures and languages. ${ }^{55}$ This included funding for immigrants' cultural activities. ${ }^{56}$ Cooperation denoted mutual tolerance and solidarity between immigrants, national minorities and ethnic Swedes. ${ }^{57}$

\footnotetext{
${ }^{50}$ SOU 1966: 55, 225-226.

${ }^{51}$ Prop. 168: 142, 106-108. For a review see also Dahlström Rhetoric, Practice and the

Dynamics of Institutional Change, 296-298.

52 SOU 1967,18, s. 165 ff, Prop. 1968,142, s. 47 ff., Dahlström, Nästan välkomna, 86.

${ }^{53}$ Skolverket Rapport 228.

${ }^{54}$ Prop. 1975: 26: 15.

${ }^{55}$ Ibid.

${ }^{56}$ SOU 1974:69, 96.

${ }^{57}$ Ibid.
} 
The Bill's policy lines were specific and following Sabatier and Mazmanian ${ }^{58}$ ranked by order of priority and importance: workplace injuries and unionization, poor housing conditions, access to welfare services, state child support, retirement pension, voluntary health checks, bilingual/home language teaching and local councils' support for immigrant organizations with a national presence and at least 3000 registered members ${ }^{59}$.

The onus put on workplace injuries and unionization indicates that these were the main problems relating to immigrants. They also reflect the configuration of power and interest that was in favour of trade unions. Fearing that employers may use guestworkers to depress wages and undermine working conditions, the Trade Union Confederation, LO had accepted labor immigration upon the condition that unionization, equitable pay and working conditions be provided to these guestworkers. It had also obtained the right to request the stop of this immigration if conditions become unfavourable for native workers. ${ }^{60}$

\section{B) Referrals to State Cultural Policies}

Moreover, Prop. 1975:26 referred to the state cultural policy Bills for more contents and elaboration. These multicultural policy provisions were also published earlier and were intensively debated in the parliament. ${ }^{61}$ Recognition of immigrants' cultures and material support for their preservation, the two variables of the Multiculturalism Policy Index were present. SOU 1972: 66, ${ }^{62}$ the first cultural policy report released in 1972 mentioned that the cultural situation of immigrants was abysmal. They were cut off from society because of their lack of Swedish language skills and knowledge of the society cultural codes. They also lacked the means of preserving their own cultural traditions. Previous policy initiatives had aimed only at state cultural institutions and ignored ethnic associations whose activities form the backbone of immigrants' cultural life ${ }^{63}$. The final cultural policy Bill, Prop. 1974:28 New Cultural Policy "Ny Kulturpolitik " ${ }^{* 4}$ published in 1974 touted multiculturalism as the remedy. In two sections called 'Insatser för Eftersatta Grupper' (Measures for disadvantaged groups) and 'Gemenskap och Aktivitet' (Community and Activity), the report called for the 'systematic' monitoring of the cultural situation of immigrants, financial support to cultural associations that, in light of their close links and wealth of experience with immigrants, were considered the most

\footnotetext{
${ }^{58}$ Sabatier and Mazmanian, Effective Implementation Policy, 10.

59 Prop. 1975: 26, 21-22.

${ }^{60}$ Johansson 2008 Så gör vi inte här i Sverige, 122-123.

${ }^{61}$ Tawat, The Birth of Sweden's Multicultural Policy.

${ }^{62}$ SOU 1966: 72 Ny Kultur Politik

${ }^{63}$ SOU. 1972:66. Ny Kultur Politik. [New Cultural Policy], 293.

${ }^{64}$ Tawat, The Birth of Sweden's Multicultural Policy, 11
} 
effective mechanism of implementation. ${ }^{65}$ While at first, Prop. 1974: 28 referred to the 1975 Integration Policy for concrete measures, ${ }^{66}$ the later referred back to it. These concrete measures were finally designed and included in Prop. 1974:28's annex, Prop. 1975:20 On the State Cultural Policy 2 “Om kulturpolitiken 2.”

\section{The Freedom of Choice Goal: The Tip}

\section{A) A Multicultural Goal}

The Freedom of Choice Goal incorporated a multicultural vision insofar as in its description, policymakers mandated state affirmation and funding for immigrants cultures. In SOU 1974:69, the preliminary report of Prop. 1975: 26, it was stated that immigrants should be given "genuine opportunities' to preserve and develop their languages and cultural traditions as the resident majority or adopt Swedish culture."67 This entails that immigrant groups receive financial support and other kinds of support to develop cultural activities of their own'. While there were elements of assimilation and preparationism, these were non-coercive as the use of the conditional tense and the notion of free will included in the definition attest. "Actions aiming at preserving immigrants' cultures and their children", it was noted "will make their reintegration easier at home if they chose to return". ${ }^{68}$ Without free will, the Goal would have amounted respectively to state-mandated assimilation and expulsion. Notions that were far from policymakers' intentions. From the onset, Swedish policymakers had clearly expected a good percentage of labour migrants to remain in the country and another to return home. They did not implement a formal guestworker system as in Germany and Switzerland, sought deliberately to repatriate labor migrants or encourage them to do so which would be expulsion not gentle preparation. Policymakers did not make any demand on immigrants to assimilate into the majority culture either. This also means that the Goal did not amount to interculturalism that gives special consideration to the national culture, and which the debates and modifications that occurred in the 1980s and 1990s as argued by Dahlström ${ }^{69}$ showcase.

\section{B) Neither stitched, nor Stretched}

The Goal does not appear to have been "stitched" during its formulation. That is, as mentioned before cobbled together as a compromise between differing problem definitions. While the Goal was added at the last minute, it was not debated at all as the

\footnotetext{
${ }^{65}$ Prop. 1974:28, 299-300.

${ }^{66}$ Prop. 1975: 20: $234 \mathrm{ff}$.

${ }^{67}$ SOU 1974:69, 95.

${ }^{68}$ SOU 1974:69, 96. Emphasis is that of the author.

${ }^{69}$ Dalhström, Rhetoric, Practice and the Dynamics of Institutional Change.
} 
drafters of the second Integration Bill in 1985 mentioned in their investigation. ${ }^{70}$ Sven Allur Reinans, a member of the drafting commission of the 1975 integration policy Bill and a longtime actor in Swedish migration policy disclosed that:

the three goals were invented by those (probably the main secretary) writing the proposition at the very last moment, and were not at all discussed, or even known by the others in the committee. But they sounded so well - you know, the French Revolution - so they were accepted in the final text $^{71}$

Arguably, stitching occurred instead as drafters tried to conceptualize the terms "immigrants" and "minority." Policymakers and experts were unable to clearly define their object of study. They were torn between handling immigrant issues at the same time with historic minorities such as Jews, Finnish-speaking Tornedalians, Swedish-Finns and Roma. Meanwhile the government had prohibited them of dealing with Saami issues. ${ }^{72}$ They postulated that once immigrants have resided in the country for a number of years, they joined the rank of national minorities as opposed to landed immigrants who faced more considerable problems of social adjustment. In this scenario, patterned after Barth's boundary theory, groups' identities were considered as fluid and the "boundary" itself was the length of residency in the territory and not bounded cultural entities. The Commission stated that:

To distinguish between immigration and minority issues would not be a good answer to the current situation in Sweden. For this reason, the Commission on Integration treated immigrant and minority issues as parts of one and the same problem area. The Commission has chosen to use the concept of linguistic minorities for both newly immigrated persons and established minorities. ${ }^{73}$

However, in the end the Commission mainly examined issues relating to immigrants at the expense of national minorities. Yet the Bill included "minority" in his title. A separate policy for national minorities that led to the establishment of regional parliaments for Saami and special status being given to historic minorities and their languages was adopted years later.

Likewise the Goal was not "stretched". That is, as defined before, turned into "vague, amorphous conceptualizations' outside its original meaning. A non-exhaustive but rigorous mapping of the concept shows that it was present in other policy domains and more importantly retained the same basic meaning. That is in logical terms, an intersection "OR". It was used in social policy" and cultural policy for various

\footnotetext{
${ }^{70}$ Prop. 1985/86:98: 19-20.

${ }^{71}$ Email Correspondence with Ingegerd Municio-Larsson, June 2011.

${ }^{72}$ SOU: 1974: 69, 93.

${ }^{73}$ Ibid.

${ }^{74}$ Sejersted, The Age of Social Democracy: Norway and Sweden.
} 
characterizations including multiculturalism. In 1962, Harry Schein, a popular cultural figure who was the Director of the Swedish Institute used the term in his influential book 'Har Vi Råd med Kultur?' (Can We Afford Culture?) to argue that cultural policy in general should be characterised by freedom of choice between viable alternatives and freedom from bad art which is obtained when an artist is spiritually independent and receives incentives ${ }^{75}$.

The term was also used during the debate on multiculturalism in 1967 by Hammarberg and Wästberg in the title of their article 'Valfrihet at invandrare? (Freedom of Choice for Immigrants!). In this article, they argued that Sweden inevitably would become a country of immigration and immigrants' cultures could enrich the society. After that, the concept appeared in the Swedish Immigration Board (SIV)'s feedback, "remiss" on SOU 1972: 66, the preliminary Report of the first Cultural Policy, Prop. 1974: 28. SIV recommended that immigrants be offered the means of choosing between preserving their cultures and adopting the Swedish culture. ${ }^{76}$

During the plenary session of this Cultural Policy Bill, the Conservative parliamentarian Mågard declared that cultural policy in general should be based on freedom and freedom of choice with the aim of creating a rich and diverse cultural life that makes enough room for personal initiative and invites every social group to take part in the cultural life ${ }^{77}$. In this vein, the concept reflected immigrants' strategies of acculturation uncovered by John Berry in his seminal article, "Acculturation and Adaptation in a New Society." ${ }^{78}$ In this article, Berry identifies four strategies immigrants implement in their contact with the host society: strong identification with the host culture (assimilation), low identification with either the host culture, or the home culture (marginalization), strong identification with the home culture (separation) and strong identification with both home and host cultures (integration).

\section{A similar mode of policymaking in Norway}

Moreover, the presence of a similar policymaking mode - more socioeconomic issues in official integration policies and more multicultural policy provisions in cultural policies

\footnotetext{
75 Schein, Har vi råd med kultur? 256; SOU 1972: 66, p. 144.

${ }^{76}$ SOU 1972: 66.

${ }^{77}$ Riksdagens Protokoll 1974 Nr 88, pp. 32- 34.

${ }^{78}$ Berry, Acculturation and Adaptation.
} 
- in a similar country, Norway, constitutes a strong counterfactual. ${ }^{79}$ In Norway, as Valenta and Bunar ${ }^{80}$ have argued, official integration policies focused mostly on socioeconomic integration namely employment and housing issues and later on language education. Like in Sweden, multicultural policy provisions including the Freedom of Choice Goal were incorporated in the first state cultural policy, St.Meld. nr. 52 (1973/1974) of 29 March 1974. The meaning assigned clearly affirmed immigrants' cultures and not preparationism. The wording of the document presents no ambiguity and in this sense is better than the Swedish text from which it however diffused. ${ }^{81}$ On page 29, in the section "andra grupper" (Other Groups) it is stated that:

The Ministry thinks that it is important that the state takes special responsibility for other cultural minorities (immigrants and guestworkers) besides the actions carried out by the counties and municipalities. It is underlined that these groups must have the same rights and aspirations as others to the same outcome and experiences... Immigrants must themselves choose whether in the long term, they want to be assimilated as to become Norwegians or if they want to keep their cultures... the drafters point out in particular the valuable contribution to our culture that immigrants can make with theirs.

Similar provisions were included in the Immigration Bill St. Meld. nr. 39 (1973-1974) Om innvandringspolitikken (About Immigration Policy) published on 14 March 1974, two weeks before the Cultural Policy Bill St. Meld. nr. 52. The Bill states on page 8 that:

Concerning immigrants' relationship to the Norwegian society, the main question is whether they must be assimilated (absorbed in the national community and be integrated) or one must take into account the fact that they will leave the country shortly. The Government's position is that the decision must not be imposed in one or another direction. The right thing to do is for immigrants to have, to the extent that is possible, the means to choose what kind of relationship they want to have with the society. They must be given the freedom of choice to do so.

\section{Conclusion}

Intertwining perspectives from the policy process and immigrant integration theory, this article has shown that the controversial Freedom of Choice Goal of Bill Prop. 1975:26 represented a multicultural vision. The affirmation of immigrants' cultures and material support to these cultures were incorporated in the Goal description. The concept did not entail coercive preparationism (expulsion) or state-mandated assimilation that would have amounted to a policy of assimilation but emphasized the free will of immigrants. As such, the Goal also reflected immigrants' strategies of acculturation and in general, everyday multiculturalism. A bright example of the nexus between policy and society and a conceptual feat considering that these strategies were not theorized until many decades later by John Berry in his groundbreaking 1997 study.

\footnotetext{
${ }^{79}$ Tawat, the Birth of Sweden's Multicultural Policy.

${ }^{80}$ Valenta and Bunar, State Assisted Integration.

${ }^{81}$ Tawat, The Divergent Convergence of Multiculturalism Policy.
} 
Furthermore, the formulation of the Goal was neither the product of concept stitching, a compromise between competing tenders to help move forward or concept stretching that occurs when a concept is applied outside its original meaning. However, because the Bill evinced more socio-economic issues (the iceberg) despite the high visibility of the Freedom of Choice Goal and cultural issues were referred to the state cultural policy for more elaboration, the Goal constitutes only the "tip" of the iceberg. Convincingly, the same dispositions were found in a comparable case, Norway.

\section{References}

Ager, Alastair. and Strang, Alison. Indicators of Integration: Final Report. Home Office Development and Practice. Report 28. London: Home Office (2004).

Bertossi, Christophe, and Duyvendak, Jan Willem. "National Models of Immigrant Integration: The Costs for Comparative Research." Comparative European Politics 10 (2012): 238-247.

Berry, John. W. “Acculturation and Adaptation in a New Society," International Migration 30 (1992): 69-85.

Breidahl, Karen, N.. Når staten lærer: En historisk og komparativ analyse af statslig policy læring og betydningen heraf for udviklingen i den arbejdsmarkedsrettede del af indvandrerpolitikken i Sverige, Norge og Danmark fra 1970 til 2011. Aalborg: Institut for Statskundskab, Aalborg Universitet (2012).

Bleich, Erik. "From international ideas to domestic policies: Educational multiculturalism in England and France", Comparative Politics, 31, 1, (1998): 81-100.

Borevi, Karin Invandrarbyrån i Uppsala: en studie av en förvaltnings framväxt. Uppsala : Centrum för multietnisk forskning, Uppsala universitet (1993).

Breidahl, Karen, N. Når staten lærer: En historisk og komparativ analyse af statslig policy læring og betydningen heraf for udviklingen i den arbejdsmarkedsrettede del af indvandrerpolitikken i Sverige, Norge og Danmark fra 1970 til 2011. Aalborg: Institut for Statskundskab, Aalborg Universitet, (2012).

Collier, David. \& Mahon, James. E. Jr.. 'Conceptual 'stretching' revisited, Adapting categories in Comparative Analysis'. American Political Science Review, 87, (1993): 845855 . 
Dahlström, Carl. Nästan välkomna. Invandrarpolitikens retorik och praktik.Statsvetenskapliga institutionen, avhandling. Gothenburg: Göteborgs Universitet, 2004.

Dahlström, Carl. Rhetoric, Practice and the Dynamics of Institutional Change: Immigrant Policy in Sweden 1964-2000, Scandinavian Political Studies 27: 4, 2004. Email Correspondence with Ingegerd Municio-Larsson, June 2011.

Entzinger, Han. "The Dynamics of Integration Policies." In Challenging Immigration and Ethnic Relations Politics . Koopmans, Ruud, and Statham, Paul, eds. Comparative European Perspective (2000).

Favell, Adrian. "Integration Policy and Integration Research in Europe: A Review and Critique," In Citizenship Today: Global Perspectives and Practices, Aleinikoff, Alexander, T., and Klusmeyer, Douglas, B., eds. 349-400. Washington, DC, 2001.

Hague, Rod; Martin, Harrop; and Shaun, Breslin. Comparative Government and Politics: An Introduction, 4th ed. Basingstoke, 1998.

Hansen, Lars-Erik. Jämlikhet och valfrihet: En studie av den svenska invandrarpolitikens framväxt. Stockholm, 2001.

Hsieh, Hsiu-Fang and Sarah, Shannon, E. "Three Approaches to Qualitative Content Analysis.” Qualitative Health Research 15, no.9 (2005): 1277-1288.

Johansson, Jesper. "Så gör vi inte här i Sverige. Vi brukar göra så här.” Retorik och pratik i LO:s invandrarpolitik 1945-1981, PhD Diss., Växjö, Växjö University, 2008.

Jørgensen, Martin, Bak. "Dansk realisme og svensk naivitet? En analyse af den danske og svenske integrationspolitik." In Bortom stereotyperna? Invandrare och integration $i$ Danmark och Sverige eds. Hedetoft, Ulf, Petersson, Bo, and Sturfelt, 266-298. Lina. Lund and Göteborg: Centrum för Danmarksstudier and Makadam Förlag, 2006. Kungörelse. 1974:152 om beslutad ny regeringsform.

Meer, Nasar and Modood, Tarek. How does Interculturalism Contrast with Multiculturalism? Journal of Intercultural Studies, 33(2), (2011): 1-22.

Page, Edward. C, "The Origins of Policy" In Oxford Handbook of Public Policy. Moran, Michael, Rein, Martin, and Goodin, Robert, E. (eds). Oxford, 2006. 
Portes, Alejandro and Min Zhou. "The New Second Generation: Segmented Assimilation and Its Variants," Annals of the American Academy of Political and Social Sciences 530 (1993): 74-96.

Prop. 1968: 142 angående riktlinjer för utlännings politiken m. m.

Prop. 1975: 26 Om riktlinjer för invandrar- och minoritetspolitiken m. m.

Prop. 1985/86: 98 Om invandrarpolitiken.

Prop. 1990/91: 195 Om aktiv flykting- och immigrationspolitik.

Prop. 1997/1998: 16 Sverige, framtiden och mångfalden - från invandrarpolitik till integrationspolitik.

Queen's University Index of Multiculturalism Policies in Contemporary Democracies https://www.queensu.ca/mcp/immigrant-minorities Accessed 18 February 2019.

Rainey H.G.. 'A theory of goal ambiguity in public organizations'. In: J.L. Perry, ed. Research in Public Administration, Vol. 2, Greenwich, CT: JAI Press, (1993): 121-166. Regeringsformen 1974, Chapter 1, paragraph 2.

Riksdagens protokoll 1974. Nr 88.

Román, Henrik. En invandrarpolitisk oppositionell: debattören David Schwarz syn på svensk invandrarpolitik åren 1964-1993. Uppsala multiethnic papers, 0281-448X ; 31. Uppsala: Centrum för multietnisk forskning, 1994.

Runblom, Harald. "Multiculturalism in a Comparative European Perspective." Sociological Forum 9, no. 4 (1994): 623-640.

Sarstrand, Anna-Maria. De första invandrarbyråerna. Om invandrares inkorporering på kommunal nivå åren 1965-1984 [The First Integration Offices. Immigrant Integration at Local Level, 1965-1984], Licentiatavhandling i Sociologi. Växjö: Institutionen för Samhällsvetenskap, Växjö Universitet, 2007.

Sartori, Giovanni. (ed). Social Science Concepts. A Systematic Analysis, Beverly Hills, Sage, 1984.

Schein, Harry, Har vi råd med kultur? Stockholm: Bonnier, 1962. 
Schwarz, D. "Utlänningsproblemet i Sverige [The Alien Problem in Sweden].” Dagens Nyheter, October 21, 1964.

Schwarz, David. Svensk Invandrar- och Minoritetspolitik 1945-1968 [Swedish Immigrant and National Minority Policy 1945-1968]. Stockholm: Prisma, 1971.

Sejersted, Francis. 2011. The Age of Social Democracy: Norway and Sweden in the Twentieth Century. Princeton, NJ: Princeton University Press.

Soininen, Maritta. "The 'Swedish model' as an Institutional Framework for Immigrant Membership Rights.” Journal of Ethnic and Migration Studies 25, no. 4 (1999): 685 702.

SOU 1971: 51 Invandrarutredningen 1. Invandrarnas utbildningssituation. Förslag om grundutbildning i svenska för vuxna invandrare.

SOU 1972: 66 Ny kulturpolitik. Nuläge och förslag.

SOU 1972: 83 Invandrarutredningen 2 - Tolkservice. Nordisk språk- convention.

SOU 1974: 69 Invandrarutredningen 3.

SOU 1984: 58 Invandrar och minoritetspolitiken, ett slutbetänkande.

Soysal, Yasemin, Nuhoglu. Limits of Citizenship: Migrants and Postnational Membership in Europe. University of Chicago Press, 1994.

Tawat, Mahama Danish and Swedish immigrants' cultural policies between 1960 and 2006: toleration and the celebration of difference, International Journal of Cultural Policy, 20:2, 202-220, 2012.

Tawat, Mahama, “The birth of Sweden's multicultural policy. The impact of Olof Palme and his ideas”, International Journal of Cultural Policy, 25:4, 471-485, 2017.

Tawat, Mahama, Two Tales of Viking Diversity. A Comparative Study of the Immigrant Integration Policy of Denmark and Sweden, 1960-2006, PhD Dissertation, Dunedin, 2012.

Tawat, Mahama, "Understanding Convergence in Immigrant Integration Policies. The Cases of Denmark and Sweden Since 1960", 2013. Available at SSRN: https://ssrn.com/abstract=2354053 Last accessed 26 November 2019. 
Valenta, Marko, Bunar, Nihad. "State Assisted Integration: Refugee Integration Policies in Scandinavian Welfare States: the Swedish and Norwegian Experience", Journal of Refugee Studies, 23, 4, (2010): 463-483.

Weiss, Janet A. "The Powers of Problem Definition, The Case of Government Paperwork”. Policy Sciences , 22, 2, (1989): 97-121.

Wieviorka, Michel. Multiculturalism: A Concept to be Redefined and Certainly not Replaced by the Extremely Vague Term of Interculturalism, Journal of Intercultural Studies, 33, 2, (2012): 225-231.

Pottie-Sherman, Yolande and Wilkes, Rima Does size really matter? On the relationship between immigrant group size and anti-immigrant prejudice, International Migration Review, 51, 1, (2017): 218-250.

Wise, Amanda. Everyday Multiculturalism, COMPAS, Oxford University (2014). Available at http://compasanthology.co.uk/wpcontent/uploads/2014/02/Wise_COMPASMigrationAnthology.pdf Last accessed 26 November 2019. 